\title{
obituaries
}

\section{James Maguire}

\section{Formerly Clinical Director and Consultant Psychiatrist at St Bridget's Hospital, Ardee, County Louth, and Department of Psychiatry, Our Lady's Hospital, Navan, County Meath, Ireland}

The life and career of Jim Maguire were defined by the qualities that characterised Jim himself: devotion to family and friends, dedication to patient care, and a sense of adventure that was entertaining, thought-provoking and insightful. It was a privilege to know him.

Jim Maguire was born on 3 April 1950 and grew up in Dublin. A gifted student, Jim completed his secondary schooling at St Joseph's College, Fairview, and entered the Royal College of Surgeons in Ireland in 1968. He graduated in 1974 and spent his pre-registration year at Jervis Street Hospital in Dublin. Jim commenced psychiatric training in 1975 at St Patrick's Hospital and became a MRCPsych in 1978. Jim's years of training as a doctor and psychiatrist were characterised by his devotion to clinical and academic activities, and a personal style that incorporated a profound appreciation of music and the arts, a gift for inspiring friendship, and, at least in the early years, his resolutely long black hair.

In 1979, Jim became clinical tutor at St Patrick's Hospital, Dublin, reflecting his enduring interest in psychiatric training and education. Jim devoted extensive time to instructing trainees and he was coauthor of an early volume of multiple choice questions for trainees preparing for the membership MRCPsych examination. Jim completed a clinical fellowship in

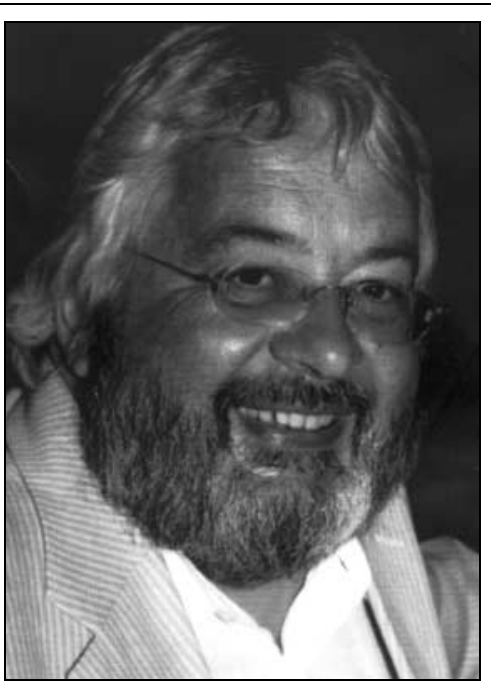

Ottawa in 1980/1981 and was appointed as a consultant psychiatrist at St Bridget's Hospital, Ardee, County Louth, in 1983. He was also clinical director of St Mary's Hospital, Drumcar, County Louth, from 1984 to 1994. In 1994, Jim was appointed as a consultant psychiatrist in the reorganised psychiatric services in south County Meath and in 2005 became clinical director of St Bridget's Hospital, Ardee, and the Department of Psychiatry at Our Lady's Hospital, Navan.

Jim's career in the psychiatric services was notable for his unfailing dedication to patient care and tireless efforts to ensure that the organisation and re-organisation of psychiatric services occurred in the best interest of patients. From the outset, Jim had a broad-based, inclusive view of mental health which was reflected in a strong interest in the role of art in mental health and illness. Jim was actively involved in organising various art exhibitions and promoting diverse art projects around Ireland. He had particular interest in the display of art-works at St Bridget's
Hospital, Ardee, and Our Lady's Hospital, Navan.

As a consultant and clinical director, Jim was a gifted educational supervisor for junior doctors at all stages of training. Leading by example, he conveyed both scientific and clinical knowledge of the practice of psychiatry and, even more importantly, unfailingly demonstrated the essentials of good and proper conduct as a doctor, clinical director and colleague. These qualities were especially valuable for trainees in the final stages of training, for whom Jim was a source of instruction, inspiration and - although he would never admit this - wisdom.

Jim had enduring interests in music, cinema, travel and art. He had an unrivalled collection of Dandy comics and memorabilia. Jim was generous in his enthusiasms and frequently bestowed gifts of books, CDs and impenetrable technological gadgets, all of which were presented with overwhelming enthusiasm. He had an endless appetite for exploration which saw him journey to distant corners of the planet, including, most recently, Vietnam and India. Jim's accounts of these adventures were vivid and memorable, and one sensed that Jim was genuinely sad (and not a little baffled) that it had not occurred to him to invite all of his friends to come on the trip.

Jim Maguire died on Good Friday, 6 April 2007, leaving behind his wife, Anne, and daughters, Aoife and Orla. He is deeply missed by family, patients and colleagues, but - as Jim himself would have viewed the matter - there is very much to remember, celebrate and enjoy from the time he spent with us.

Brendan D. Kelly

doi: 10.1192/pb.bp.108.021063 